\title{
Dotsenko $\mathbf{N}$. METHODOLOGICAL PROVISION OF HUMAN RESOURCES MANAGEMENT IN A MULTI- PROJECT ENVIRONMENT
}

Об'єктом дослідження є процеси управління людськими ресурсами проектів в мультипроектному середовищі. Проведені дослідження базуються на застосуванні комбінаторно-логічного підходу до побудови формальних моделей формування і функціонування проектних команд в мультипроектному середовищі, стейкхолдер-орієнтованого підходу до формування ресурсних вимог, донорно-акцепторного підходу до розподілу ресурсів між проектами. Основна гіпотеза дослідження полягає в припущенні, що результативність управління проектами залежить від ефективності управління людськими ресурсами проектів і програм. Це неможливо досягти без урахування існуючих ресурсних обмежень і вимог, які визначаються ключовими заиікавленими сторонами проектів. Розглянуто питання створення методологічного забезпечення управління людськими ресурсами формування адаптивних команд в мультипроектному середовищі. Показано взаємозв'язок запропонованої методології проектно-орієнтованого управління ресурсами формування адаптивних команд в мультипроектному середовищі з сучасними підходами до управління людськими ресурсами. Розроблено кониептуальну модель проектно-орієнтованого управління ресурсами формування адаптивних команд в мультипроектному середовищі. Запропоновано метод формування ресурсних вимог, заснований на аналізі зацікавленості стейкхолдерів в прощесах управління людськими ресурсами з урахуванням лояльності зацікавлених сторін. Розглянуто особливості процесу формування вимог до команди проекту. Для зменшення складності завдання формування адаптивної команди пропонується здійснити ряд перевірок. Необхідно забезпечити перевірку узгодженості вимог стейкхолдерів, перевірку відповідності рівня компетенцій претендентів необхідним, первинну перевірку коефічієнтів резервування, перевірку на наявність заборонених поєднань та первинний аналіз матриці претендентів. Розглянуто приклад формування команди при заданих обмеженнях. Обмеженнями були рівень компетениій і вартість. Застосування запропонованого підходу дозволило побудувати команду проекту при заданих функціональних вимогах, що мають максимальний рівень компетенцій при мінімальній вартості команди. Показано підвищення ефективності процесу формування команди проекту за рахунок комплексного застосування розробленого методологічного забезпечення управління людськими ресурсами проектів в мультипроектному середовищі.

Ключові слова: управління проектами, мультипроектне середовище, команда проекту, стейкхолдери проектів.

\section{Introduction}

The implementation of multi-project management as an element of ensuring the viability of a company places additional demands on the human resource management of projects in a multi-project environment [1]. Forming consistent resource requirements of the stakeholders is crucial for ensuring effective project management in a multi-project environment. The proposed methods are based on the competence approach [2], game-theoretic models of the formation and functioning of teams [3,4]. Thus, the development of methodological support for human resource management in a multi-project environment is an urgent task. The object of research is the processes of human resource management of projects in a multi-project environment. The aim of research is creation of a methodological support for human resource management in a multi-project environment.

\section{Methods of research}

The conducted studies are based on the application of the approaches described in [5-7]. The main hypothesis of the study is the assumption that the effectiveness of project management depends on the effectiveness of human resource management of projects and programs. This is im- possible to achieve without taking into account the existing resource constraints and requirements that are determined by the project stakeholders. Based on the analysis of PMI standards [8-10], taking into account the methodology of project-oriented resource management of the formation of adaptive teams in a multi-project environment [7], a conceptual model is proposed (Fig. 1). When forming adaptive project teams, it is proposed to use the method based on formal transformations [6]. A method of forming resource requirements is proposed, based on an analysis of stakeholder interest in human resource management processes, taking into account the loyalty of interested parties.

Method of formation of resource requirements:

Stage 1. Checking the consistency of stakeholder requirements (agreeing on a resource allocation strategy; coordinating the competence threshold; agreeing on resource requirements for project operations; agreeing on priorities for resource allocation between projects).

Stage 2. Primary check of the feasibility of the requirements [5].

Stage 3. Formation of generalized resource requirements [6].

Stage 4. Correction of the source data (performed if necessary).

Stage 5. Monitoring changes in team requirements. 


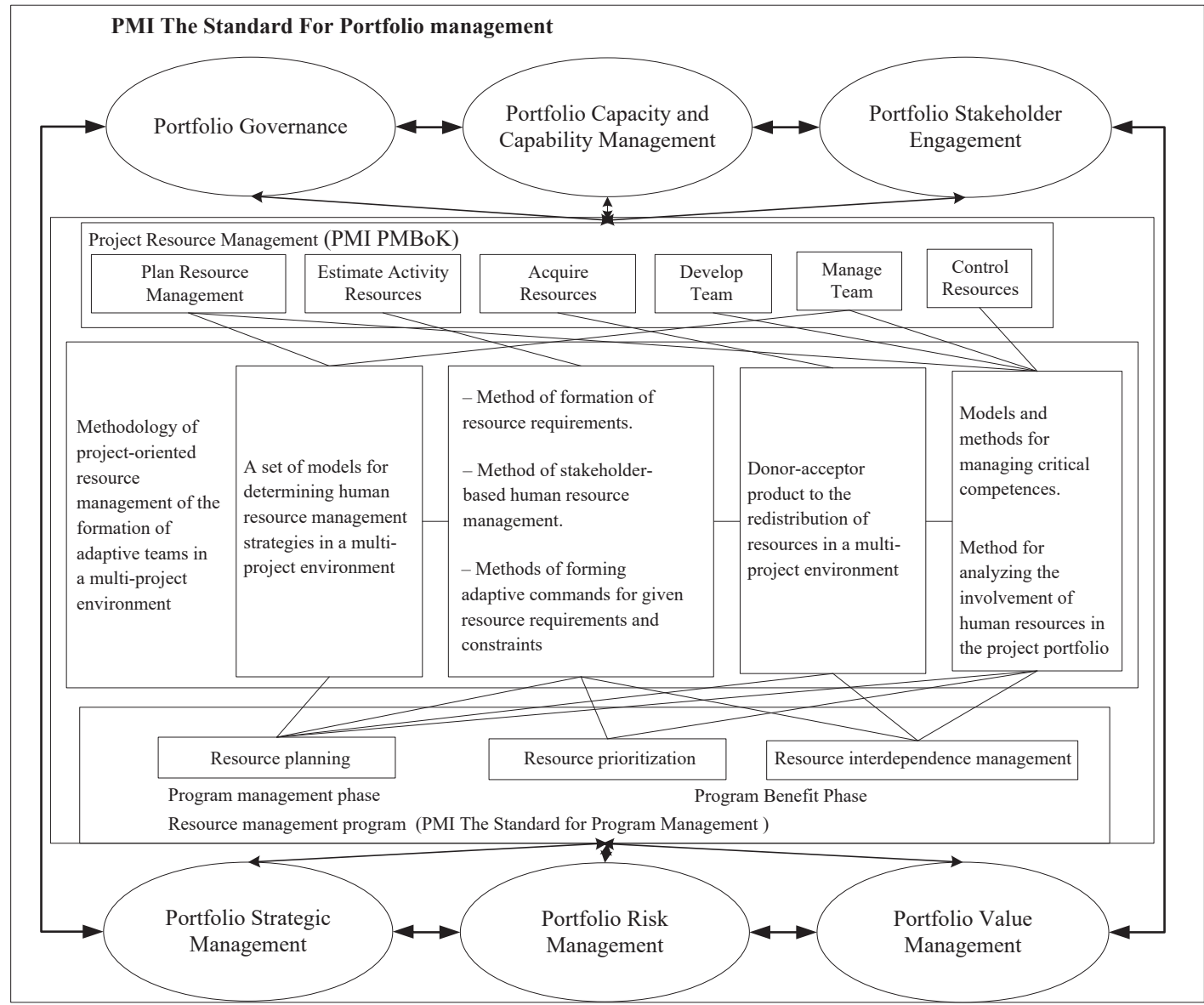

Fig. 1. The conceptual model of project-oriented resource management of the formation of adaptive teams in a multi-project environment

Formed requirements for a project team are the initial data for building project teams [5, 6].

\section{Research results and discussion}

Initial data: the set of applicants $Q=\left\{q_{1}, q_{2}, \ldots, q_{14}\right\}$, the set of functions $A=\left\{a_{1}, a_{2}, \ldots, a_{6}\right\}$, the matrix of characteristics $C_{1}$ (level of competence), $C_{2}$ (cost) (Table 1).

Table 1

Initial data

\begin{tabular}{|c|c|c|c|c|c|c|c|c|c|c|c|c|}
\hline \multirow{2}{*}{$q_{/ A}$} & \multicolumn{6}{|c|}{ Characteristics $C_{1}$} & \multicolumn{5}{|c|}{ Characteristics $C_{2}$} \\
\cline { 2 - 14 } & $a_{1}$ & $a_{2}$ & $a_{3}$ & $a_{4}$ & $a_{5}$ & $a_{6}$ & $a_{1}$ & $a_{2}$ & $a_{3}$ & $a_{4}$ & $a_{5}$ & $a_{6}$ \\
\hline $4_{1}$ & 0 & 200 & 0 & 220 & 0 & 240 & 0 & 700 & 0 & 950 & 0 & 900 \\
\hline $4_{2}$ & 300 & 0 & 0 & 270 & 0 & 0 & 700 & 0 & 0 & 500 & 0 & 0 \\
\hline $4_{3}$ & 250 & 0 & 300 & 0 & 0 & 275 & 800 & 0 & 600 & 0 & 0 & 67 \\
\hline $4_{4}$ & 0 & 140 & 0 & 200 & 0 & 0 & 0 & 700 & 0 & 850 & 0 & 0 \\
\hline $4_{5}$ & 0 & 0 & 350 & 0 & 180 & 230 & 0 & 0 & 800 & 0 & 950 & 800 \\
\hline $4_{6}$ & 310 & 0 & 310 & 0 & 0 & 200 & 700 & 0 & 1000 & 0 & 0 & 900 \\
\hline $4_{7}$ & 350 & 150 & 0 & 0 & 0 & 0 & 890 & 790 & 0 & 0 & 0 & 0 \\
\hline $4_{8}$ & 300 & 0 & 320 & 0 & 200 & 0 & 800 & 0 & 600 & 0 & 750 & 0 \\
\hline $4_{9}$ & 0 & 170 & 0 & 200 & 0 & 260 & 0 & 400 & 0 & 300 & 0 & 900 \\
\hline $4_{10}$ & 0 & 0 & 290 & 0 & 190 & 0 & 0 & 0 & 500 & 0 & 800 & 0 \\
\hline $4_{11}$ & 0 & 0 & 280 & 245 & 180 & 0 & 0 & 0 & 800 & 700 & 900 & 0 \\
\hline $4_{12}$ & 290 & 0 & 0 & 0 & 200 & 0 & 800 & 0 & 0 & 0 & 1000 & 0 \\
\hline $4_{13}$ & 0 & 190 & 0 & 260 & 0 & 0 & 0 & 900 & 0 & 800 & 0 & 0 \\
\hline $4_{14}$ & 0 & 0 & 0 & 290 & 210 & 0 & 0 & 0 & 0 & 900 & 750 & 0 \\
\hline
\end{tabular}

Determine the composition of the team with the maximum level of competence and minimum cost (priority - the level of competence) with the prohibition of combinations.

Decision.

Stage 1. Define logical functions that describe the performers who are able to perform the corresponding functions:

$$
A(Q, 1)=\left(q_{2}^{1} \mathrm{\vee} q_{3}^{1} \mathrm{\vee} q_{6}^{1} \mathrm{\vee} q_{7}^{1} \mathrm{v} q_{8}^{1} \mathrm{\vee} q_{12}^{1}\right) ;
$$

$A(Q, 2)=\left(q_{1}^{2} \vee q_{4}^{2} \vee q_{7}^{2} \vee q_{9}^{2} \vee q_{13}^{2}\right) ;$

$A(Q, 3)=\left(q_{3}^{3} \vee q_{5}^{3} \vee q_{6}^{3} \vee q_{8}^{3} \vee q_{10}^{3} \vee q_{11}^{3}\right) ;$

$A(Q, 4)=\left(q_{1}^{4} \vee q_{2}^{4} \vee q_{4}^{4} \vee q_{9}^{4} \vee q_{11}^{4} \vee q_{13}^{4} \vee q_{14}^{4}\right) ;$

$A(Q, 4)=\left(q_{5}^{5} \mathrm{v} q_{8}^{5} \mathrm{\vee} q_{10}^{5} \mathrm{\vee} q_{11}^{5} \mathrm{\vee} q_{12}^{5} \mathrm{\vee} q_{14}^{5}\right) ;$

$A(Q, 5)=\left(q_{1}^{6} \vee q_{3}^{6} \vee q_{5}^{6} \vee q_{6}^{6} \vee q_{9}^{6}\right)$.

Stage 2. Compose a generalized logical function $F[6]$.

Stage 3. The generalized logical function is reduced to a non-collision form. After transformations, the function has the form:

$$
\begin{aligned}
& F=q_{1}^{2} q_{2}^{1} q_{3}^{3} q_{4}^{4} q_{5}^{5} q_{6}^{6} \mathrm{v} q_{1}^{2} q_{2}^{1} q_{3}^{3} q_{4}^{4} q_{5}^{5} q_{9}^{6} \mathrm{v} \\
& \mathrm{v} q_{1}^{2} q_{2}^{1} q_{3}^{3} q_{4}^{4} q_{5}^{6} q_{8}^{5} \mathrm{v} q_{1}^{2} q_{2}^{1} q_{5}^{3} q_{6}^{6} q_{8}^{5} q_{13}^{4} \mathrm{v} \\
& \mathrm{v} q_{1}^{6} q_{2}^{1} q_{4}^{2} q_{5}^{5} q_{6}^{3} q_{13}^{4} \mathrm{v} q_{2}^{1} q_{3}^{6} q_{4}^{2} q_{5}^{5} q_{6}^{3} q_{13}^{4} \mathrm{v} \\
& \mathrm{v} q_{2}^{1} q_{4}^{2} q_{5}^{5} q_{6}^{3} q_{9}^{6} q_{13}^{4} \mathrm{v} q_{2}^{1} q_{4}^{2} q_{6}^{6} q_{8}^{3} q_{9}^{4} q_{12}^{5} \mathrm{v} \\
& \mathrm{v} q_{1}^{6} q_{2}^{1} q_{4}^{2} q_{8}^{3} q_{9}^{4} q_{14}^{5} \mathrm{v} q_{2}^{1} q_{3}^{6} q_{4}^{2} q_{8}^{3} q_{9}^{4} q_{14}^{5} \mathrm{v} \\
& \mathrm{v} \ldots \mathrm{v} q_{5}^{6} q_{10}^{5} q_{11}^{3} q_{12}^{1} q_{13}^{2} q_{14}^{4} \mathrm{v} q_{6}^{6} q_{10}^{5} q_{11}^{3} q_{12}^{1} q_{13}^{2} q_{14}^{4} \mathrm{v} \\
& \mathrm{v} q_{9}^{6} q_{10}^{5} q_{11}^{3} q_{12}^{1} q_{13}^{2} q_{14}^{4} .
\end{aligned}
$$


The obtained result reflects the possible variants for building a team and the distribution of functions between performers.

Stage 4. For given matrices of characteristics $C$, determine the total characteristic of the implementation of functions by the command $C_{1}^{\text {com }}$ and $C_{2}^{\text {com }}$. Table 2 shows the characteristics of variants and the distribution of functions in variants.

Table 2

Variants of building project teams

\begin{tabular}{|c|c|c|c|c|c|c|c|c|c|c|c|c|c|c|c|c|c|}
\hline \multirow{2}{*}{$\begin{array}{c}\text { Va- } \\
\text { riant }\end{array}$} & \multicolumn{15}{|c|}{ Performers } & \multirow{2}{*}{$\Sigma_{1}^{\text {com }}$} & \multirow{2}{*}{$L_{2}{ }^{\mathrm{com}}$} \\
\hline & 41 & 42 & 43 & 94 & 45 & 46 & 47 & $4 \mathrm{\varepsilon}$ & 49 & $q_{1}$ & & & 12 & 413 & $q_{14}$ & & \\
\hline 1 & 2 & 1 & 3 & 4 & 5 & 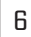 & 0 & 0 & 0 & 0 & & & Ј & 0 & 0 & 1380 & 4700 \\
\hline 2 & 2 & 1 & 3 & 4 & 0 & 6 & 0 & 0 & 0 & 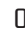 & & & ] & 0 & 0 & 1380 & 4650 \\
\hline 3 & 2 & 1 & 3 & 0 & 0 & 6 & 0 & 0 & 4 & c & & & 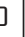 & 0 & 0 & 1380 & 410 \\
\hline 4 & 2 & 1 & 0 & 4 & 5 & 0 & 0 & 0 & 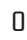 & 3 & & & & 0 & 0 & 1370 & 460 \\
\hline .. & . & & 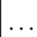 & & .. & & 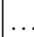 & & & & & & & $\ldots$ & & .. & \\
\hline 24 & 0 & 0 & 1 & 2 & 5 & 6 & 0 & 0 & & c & & & & 0 & 0 & 1250 & 4450 \\
\hline
\end{tabular}

Team building variants 1-3 have a maximum level of competence - 1380. The third variant has the minimum cost: $q_{1}, q_{2}, q_{3}, q_{6}, q_{9}, q_{11}$. The application of the proposed approach allows reducing the cost of the project team by $13 \%$ while ensuring the specified restrictions.

\section{Conclusions}

The issues of creating a methodological support for human resources management of forming adaptive teams in a multi-project environment are considered. A conceptual model of project-oriented resource management of the formation of adaptive teams in a multi-project environment is developed. Its peculiarity is the establishment of the relationship between the processes of project-oriented resource management of the formation of adaptive teams in a multi-project environment with the resource management processes of projects, programs and project portfolios. A method for the formation of resource requirements is proposed. Its essence lies in the fact that based on the analysis of the requirements of stakeholders, the generalized agreed resource requirements for projects in a multiproject environment are formed. By analyzing the interest of stakeholders in human resource management processes and taking into account the loyalty of stakeholders, it is possible to formulate agreed resource requirements for the task of forming an adaptive project team. An example of the formation of a team with given restrictions is considered. The application of the proposed approach will improve the efficiency of project management in a multi-project environment by forming teams that meet certain requirements.

\section{References}

1. The Study of Multi-Project Resource Management Method Suitable for Research Institutes from Application Perspective Li X. B. et. al. // Procedia Engineering. 2017. Vol. 174. P. 155-160. doi: http://doi.org/10.1016/j.proeng.2017.01.191

2. Bushuev S. D., Bushuev D. A. Osnovy individual'nykh kompetentsiy dlya Upravleniya proektami, Programmami i Portfelyami (National Competence Baseline, NCB Version 4.0). Upravlenie portfelyami proektov. Vol. 1 / ed. by Bushuev S. D. Kyiv: Sammit-Kniga, 2017. 168 p.

3. Novikov D. A. Matematicheskie metody formirovaniya i funktsionirovaniya komand. Moscow: Izdatel'stvo fiziko-matematicheskoy literatury, 2008. $184 \mathrm{p}$.

4. Burkov V. N., Korgin N. A., Novikov D. A. Problemy kompleksirovaniya i dekompozitsii mekhanizmov upravleniya oraginzatsionno-tekhnicheskimi sistemami // Problemy upravleniya. 2016. Issue 5. P. 14-23.

5. Dotsenko N. V., Sabadosh L. Yu., Chumachenko I. V. Metody upravlinnia liudskymy resursamy pry formuvanni komand multyproektiv ta prohram: monograph. Kharkiv: KhNUMH im. O. M. Beketova, 2015. 201 p.

6. Dotsenko N. V. Kombinatorno-lohichnyi pidkhid do pobudovy formalnykh modelei formuvannia ta funktsionuvannia proektnykh komand // Vcheni zapysky Tavriiskoho natsionalnoho universytetu imeni V. I. Vernadskoho. Seriia: Tekhnichni nauky. 2018. Vol. 29, Issue 5 (68). Part 1. P. 105-109.

7. Dotsenko N. V. Metodolohichni osnovy upravlinnia liudskymy resursamy pry hnuchkomu upravlinni v multyproektnomu seredovyshchi // Matematychni modeli ta novitni tekhnolohi upravlinnia ekonomichnymy ta tekhnichnymy systemamy: monograph / ed. by Timofieiev V. O., Chumachenko I. V. Kharkiv: FOP Panov A.M., 2018. P. 243-251.

8. The standard for Program Management. Project Management Institute, 2013. 176 p.

9. The standard for portfolio management. Newtown Square: Project Management Institute, 2017. 127 p.

10. A Guide to the Project Management Body of Knowledge PMBOK. Project Management Institute, 2017. 726 p.

Dotsenko Nataliia, PhD, Associate Professor, Department of Management, National Aerospace University H. E. Zhukovsky «Kharkiv Aviation Institute», Ukraine, e-mail: nvdotsenko@gmail.com, ORCID: http://orcid.org/0000-0003-3570-590 